University of Nebraska - Lincoln

DigitalCommons@University of Nebraska - Lincoln

Nebraska Cooperative Fish \& Wildlife Research Nebraska Cooperative Fish \& Wildlife Research Unit -- Staff Publications

1998

\title{
Larval Black Crappie Distribution: Implications for Sampling Impoundments and Natural Lakes
}

\author{
Kevin L. Pope \\ Texas Tech University, kpope2@unl.edu \\ David W. Willis \\ South Dakota State University
}

Follow this and additional works at: https://digitalcommons.unl.edu/ncfwrustaff

Part of the Other Environmental Sciences Commons

\footnotetext{
Pope, Kevin L. and Willis, David W., "Larval Black Crappie Distribution: Implications for Sampling Impoundments and Natural Lakes" (1998). Nebraska Cooperative Fish \& Wildlife Research Unit -- Staff Publications. 66.

https://digitalcommons.unl.edu/ncfwrustaff/66
}

This Article is brought to you for free and open access by the Nebraska Cooperative Fish \& Wildlife Research Unit at DigitalCommons@University of Nebraska - Lincoln. It has been accepted for inclusion in Nebraska Cooperative Fish \& Wildlife Research Unit -- Staff Publications by an authorized administrator of DigitalCommons@University of Nebraska - Lincoln. 
North American Journal of Fisheries Management 18:470-474, 1998

(C) Copyright by the American Fisheries Society 1998

\title{
Larval Black Crappie Distribution: Implications for Sampling Impoundments and Natural Lakes
}

\author{
Kevin L. Pope*1 and David W. Willis \\ Department of Wildlife and Fisheries Sciences \\ South Dakota State University, Brookings, South Dakota 57007, USA
}

\begin{abstract}
An understanding of larval fish distributions is essential for developing an appropriate sampling design to monitor larval abundances. We monitored abundance of larval black crappie Pomoxis nigromaculatus to assess spatial differences in Richmond Lake (a 336-ha impoundment) and Brant Lake (a 405-ha natural lake), South Dakota, during 1994-1996. Age-0 black crappies were collected with a $500-\mu \mathrm{m}$ mesh ichthyoplankton trawl from fixed sites within each water body. In the impoundment, larval black crappies were collected over a longer period at the upper site than at the dam site during 1994 and 1995. In the natural lake, larval black crappie abundances were similar between east and west sites during all 3 years. In light of our results, biologists should spatially stratify sampling sites when collecting larval black crappies in impoundments such as Richmond Lake, whereas random sites may be more appropriate in natural lakes such as Brant Lake.
\end{abstract}

An understanding of larval fish distribution is essential in determining an appropriate sampling design to monitor larval abundance. Distributions of larvae vary temporally and spatially (Kelso and Rutherford 1996), and this variation should be considered when designing a study. Numerous studies have examined temporal and spatial variations of larval fishes in freshwater lentic systems (e.g., Werner 1969; Storck et al. 1978; Tuberville 1979; Faber 1980; Conrow et al. 1990). Mitzner (1987) examined spatial differences of larval $(<15$ d) crappies Pomoxis spp. in Rathbun Lake, Iowa. Although white crappies $P$. annularis and black crappies $P$. nigromaculatus are similar in a number of characteristics, several important differences exist between these two species. For example, temporal differences exist between larval abundances of white and black crappies, with larval black crappies consistently collected earlier than larval white crappies in southeastern Louisiana waters (Chatry and Conner 1980). In addition, juvenile white crappies primarily fed near the bottom, while juvenile black crappies fed near the surface in Rough

\footnotetext{
* Corresponding author.

${ }^{1}$ Present address: Texas Tech University, Department of Range, Wildlife, and Fisheries Management, Lubbock, Texas 79409, USA.
}

River Lake, Kentucky (Overmann et al. 1980), which suggests that spatial differences in juvenile white and black crappies also exist. Because temporal and spatial differences probably exist between white and black crappies, a distributional assessment of larval black crappies was still needed. Thus, we monitored larval black crappie abundances to assess spatial differences in Richmond and Brant lakes, South Dakota, during 1994-1996.

\section{Study Sites}

Richmond Lake is a 336-ha impoundment in northeastern South Dakota (Brown County). The impoundment has a shoreline development index of 5.8 , mean depth of $4.6 \mathrm{~m}$, maximum depth of $8.8 \mathrm{~m}$, morphoedaphic index of 71 , and does not thermally stratify during summer. The watershed is primarily agricultural land, of which $48 \%$ is cropland and $52 \%$ is pasture (Koth 1981). The black crappie population is characterized by high density (Guy and Willis 1993), slow growth (Guy and Willis 1995a), and relatively consistent recruitment (Guy and Willis 1995b).

Brant Lake is a 405-ha natural lake in eastern South Dakota (Lake County). The lake has a shoreline development index of 1.2, mean depth of 3.4 $\mathrm{m}$, maximum depth of $4.3 \mathrm{~m}$, morphoedaphic index of 191, and does not thermally stratify during summer. The watershed is primarily agricultural land, of which $93 \%$ is cropland and $7 \%$ is pasture (Koth 1981). The black crappie population is characterized by low density (Guy and Willis 1993), fast growth (Guy and Willis 1995a), and inconsistent recruitment (Guy and Willis 1995b).

\section{Methods}

Larval black crappies were sampled weekly from late spring through summer with a 0.76-mdiameter ichthyoplankton net (bar mesh size $=500$ $\mu \mathrm{m})$ towed (mean tow speed $\pm \mathrm{SE}$ of all trawls made during 1994-1996 was $1.0 \pm 0.001 \mathrm{~m} / \mathrm{s}$ ) just under the surface during daylight. Two consecutive tows were collected at four standardized sites in each water body on each sampling date (Figures $1,2)$. Thornton's reservoir zonation model (Thorn- 


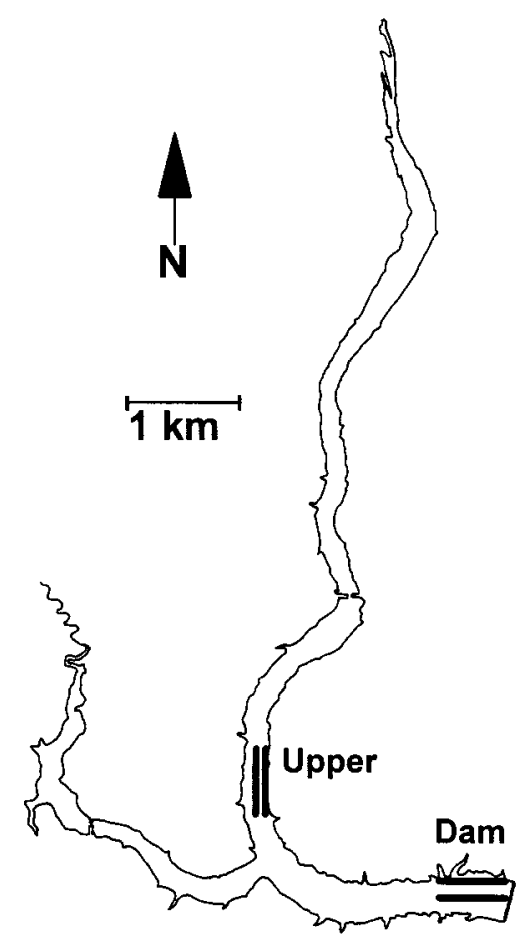

FiguRE 1.-Surface trawl sites (dark bars) for larval black crappies during 1994-1996 at Richmond Lake, South Dakota, showing upper and dam sites. Nearshore and open-water trawls were made at each location, and two consecutive trawls were made at each site (i.e., each bar).

ton et al. 1981; Thornton 1990) recognizes a longitudinal gradient along reservoirs. Thus, sites were stratified by location (upper and lower) for Richmond Lake. Sites were stratified by location (east and west) for Brant Lake because water flow differed in these two areas (i.e., most water enters Brant Lake from the northwest and the outflow is on the southwest end; Figure 2). Tows were made in nearshore ( $\leq 20 \mathrm{~m}$ from shore) and open-water (80-130 $\mathrm{m}$ from shore for Richmond Lake and $\geq 400 \mathrm{~m}$ for Brant Lake) habitats at both locations of each water body. A flowmeter mounted in the mouth of the net allowed estimation of the volume of water filtered, and hence, larval density (number $/ \mathrm{m}^{3}$ ). Differences in larval black crappie abundances between sites (i.e., upper and dam for Richmond Lake; east and west for Brant Lake) within each year were analyzed with a split-plot repeatedmeasures analysis of variance (Maceina et al. 1994). Each sample collected was used as a replicate observation for analyses.

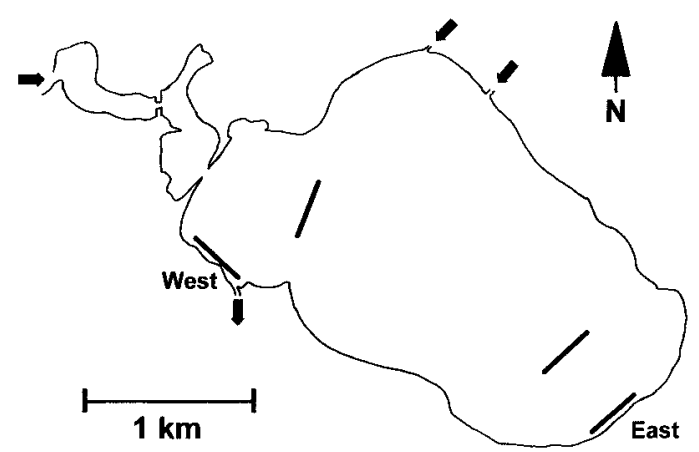

FiguRE 2.- Surface trawl sites (dark bars) for larval black crappies during 1994-1996 at Brant Lake, South Dakota, showing east and west sites. Nearshore and openwater trawls were made at each location, and two consecutive trawls were made at each site (i.e., each bar). Water inflows and outflow are indicated with arrows.

\section{Results}

Larval black crappie abundances in Richmond Lake peaked 1 week earlier at the dam site than at the upper site during 1994 (Figure 3). The reverse occurred during 1995. Peaks were simultaneous during 1996. No significant differences in larval abundances were found between dam and upper sites within a given year $(P>0.16$; Table 1). However, the treatment $\times$ date interactions were significant during 1994 and $1995(P \leq 0.025)$ but not during $1996(P=0.64)$. Larval black crappies were collected over a longer period at the upper site than at the dam site during 1994 and 1995.

In Brant Lake, the timing of peak larval black crappie abundances was similar between east and west sites during 1994 and 1996 (Figure 4). Larval black crappie abundances were not significantly different between east and west sites during 1994, 1995, or $1996(P>0.5$; Table 1$)$, and the treatment $\times$ date interactions were not significant $(P>0.2)$.

\section{Discussion}

Biologists should consider trawl site selection when collecting larval black crappies. Temporal differences were observed in larval black crappie abundance between dam and upper sites in Richmond Lake. This may be a result of black crappies not spawning uniformly throughout a water body. For example, Pope and Willis (1997) found suspected nests of ultrasonic-tagged male black crappies in the upper arms of Richmond Lake but not in small coves near the dam. In addition, Mitzner (1987) related spatial differences between abun- 


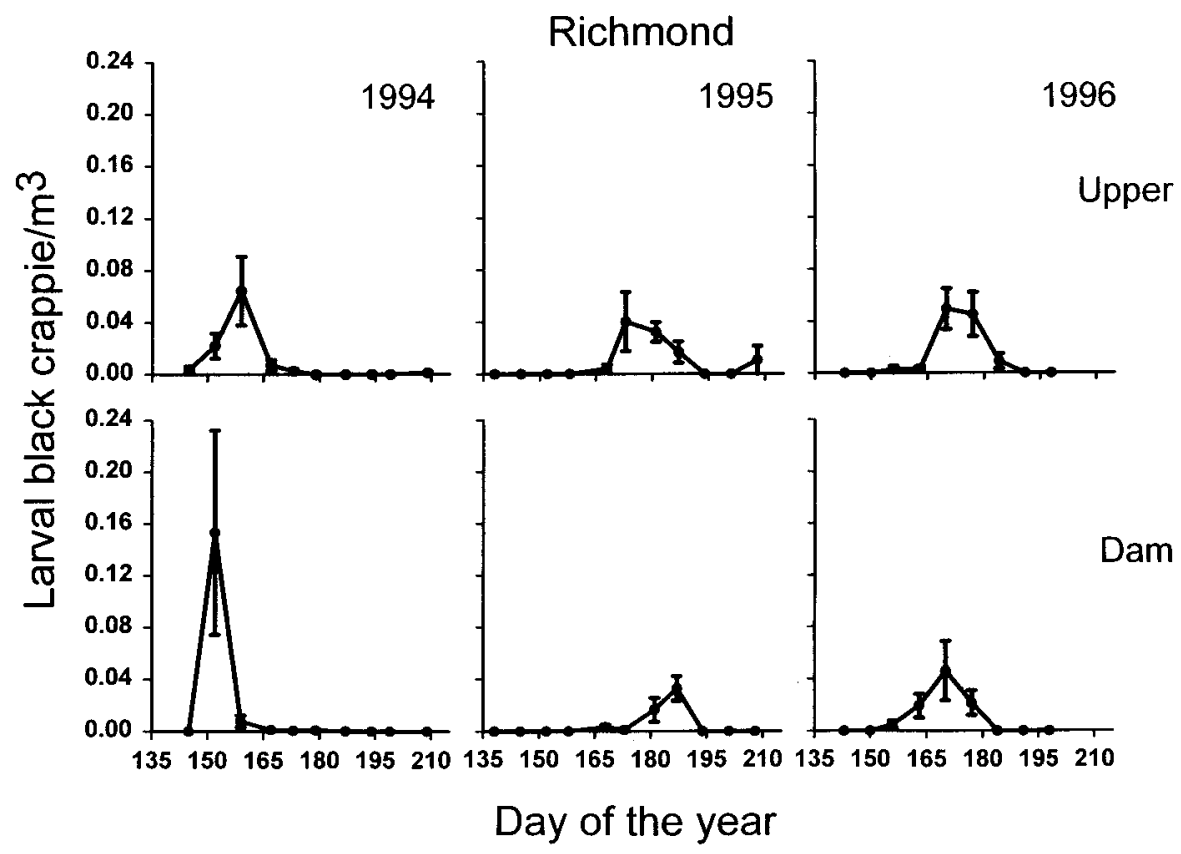

FIGURE 3.-Larval black crappie abundance (mean \pm SE) in Richmond Lake, South Dakota, during 1994-1996 at stratified sites of upper and dam. Day of year 150 is 30 May 1994, 30 May 1995, and 29 May 1996; day of year 180 is 29 June 1994, 29 June 1995, and 28 June 1996.

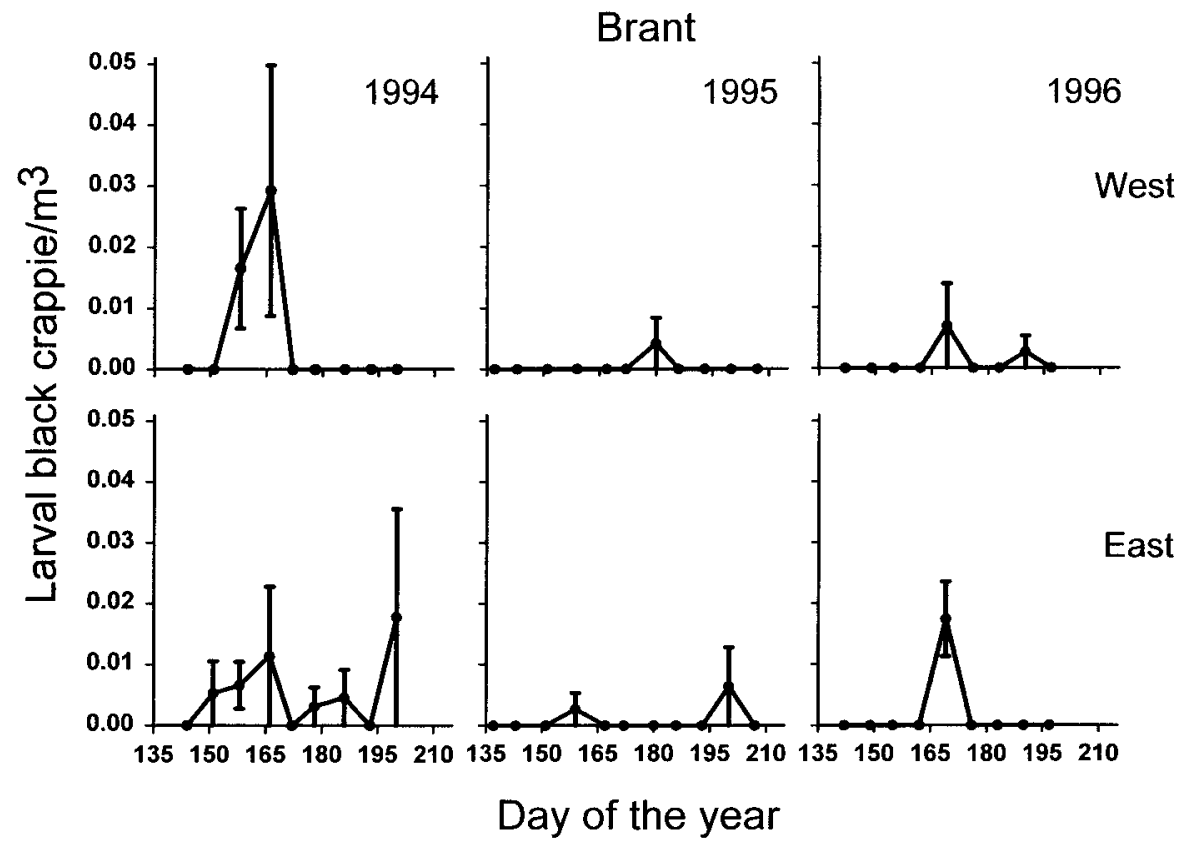

FIGURE 4.- - Larval black crappie abundance (mean \pm SE) in Brant Lake, South Dakota, during 1994-1996 at stratified sites of east and west. Day of year 150 is 30 May 1994, 30 May 1995, and 29 May 1996; day of year 180 is 29 June 1994, 29 June 1995, and 28 June 1996. 
TABLE 1.-Statistical comparisons (split-plot repeatedmeasures analysis of variance; Maceina et al. 1994) of larval black crappie abundance (number $/ \mathrm{m}^{3}$ ) estimated from collection with a $500-\mu \mathrm{m}$-mesh ichthyoplankton net in Richmond and Brant lakes, South Dakota. Statistical tests were made between locations (upper and dam for Richmond Lake; east and west for Brant Lake) within each year of sampling. The $F$-value $(F)$, degrees of freedom (df), and the probability $(P)$ of observing a larger test statistic are provided for treatment and for the treatment $x$ date interaction; $P$-values $\leq 0.05$ are marked with an asterisk.

\begin{tabular}{|c|c|c|c|c|c|c|}
\hline \multirow[b]{2}{*}{ Year } & \multicolumn{3}{|c|}{ Treatment } & \multicolumn{3}{|c|}{ Treatment $\times$ date } \\
\hline & $F$ & df & $P$ & $F$ & df & $P$ \\
\hline \multicolumn{7}{|c|}{ Richmond Lake } \\
\hline 1994 & 2.28 & 1,6 & 0.182 & 7.11 & 9,51 & $0.0001 *$ \\
\hline 1995 & 2.53 & 1,6 & 0.163 & 2.27 & 10,60 & $0.025 *$ \\
\hline 1996 & 0.27 & 1,6 & 0.624 & 0.76 & 8,48 & 0.635 \\
\hline \multicolumn{7}{|c|}{ Brant Lake } \\
\hline 1994 & 0.01 & 1,6 & 0.912 & 0.80 & 8,47 & 0.604 \\
\hline 1995 & 0.43 & 1,6 & 0.535 & 1.05 & 10,60 & 0.417 \\
\hline 1996 & 0.48 & 1,6 & 0.515 & 1.41 & 8,48 & 0.216 \\
\hline
\end{tabular}

dances of larval ( $<15 \mathrm{~d}$ ) crappies (white and black combined) to nearby available spawning habitat.

In Brant Lake, no differences in larval black crappie abundance existed between east and west sites during 1994-1996. Thus, site stratification does not appear necessary for future larval black crappie sampling in Brant Lake, even though black crappies spawned in the west bay of Brant Lake (Pope and Willis 1997). Larval black crappies appeared to have little difficulty dispersing throughout the entire lake basin. Dispersion of the larvae may be facilitated by wind and wave turbulence that is common in water bodies that have a low shoreline development index, such as Brant Lake.

Based on our results, biologists should consider sampling site selection when collecting larval black crappies. In waters where larval black crappies are dispersed quickly throughout the entire system (such as Brant Lake), a completely randomized sampling design appears appropriate and should simplify statistical analyses. However, in waters where black crappies spawn in specific areas and larvae do not quickly disperse throughout the entire system (such as Richmond Lake), a stratified sampling design is appropriate. Fixed or random stations within a stratified area should be selected on the basis of the researcher's needs. If biologists are unaware of the biology of larval black crappie in the water body of interest, then we recommend that they develop a stratified sam- pling design and determine whether spatial and temporal differences exist.

\section{Acknowledgments}

We thank C. Guy and D. DeVries for their input in planning this research. Statistical advice was provided by M. Brown and Z. Wicks III. We thank the following individuals for their help in the field and laboratory: M. Anderson, K. Barnick, D. Beck, S. Crow, D. Dieterman, R. Doorenbos, M. Flammang, D. Franke, B. Frolich, C. Guy, R. Hanten, Jr., S. Fisher, S. Gangl, W. Geraets, K. Hurley, T. Loomis, D. Lucchesi, R. Mauk, J. Mizzi, N. Mueller, R. Neumann, J. Pope, K. Pope, N. Pope, S. Pope, C. Pyle, S. Rustin, A. Starostka, B. Van Zee, and A. Wolf. In addition, W. Duffy, R. Pengra, S. Sammons, C. Scalet, L. Widvey, and A. Zale provided helpful comments on earlier drafts of this manuscript. This work was funded in part by Federal Aid in Sport Fish Restoration, project F-15R, study 1552, administered by the South Dakota Department of Game, Fish and Parks. This manuscript was approved for publication by the South Dakota Agricultural Experiment Station as Journal Series 3012.

\section{References}

Chatry, M. F., and J. V. Conner. 1980. Comparative development morphology of the crappies, Pomoxis annularis and $P$. nigromaculatus. Pages 45-57 in L. A. Fuiman, editor. Proceedings of the fourth annual larval fish conference. U.S. Fish and Wildlife Service Biological Services Program FWS/OBS-80/43.

Conrow, R., A. V. Zale, and R. W. Gregory. 1990. Distributions and abundances of early life stages of fishes in a Florida lake dominated by aquatic macrophytes. Transactions of the American Fisheries Society 119:521-528.

Faber, D. J. 1980. Observations on the early life of the golden shiner, Notemigonus crysoleucas (Mitchill), in Lac Heney, Québec. Pages 69-78 in L. A. Fuiman, editor. Proceedings of the fourth annual larval fish conference. U.S. Fish and Wildlife Service Biological Services Program FWS/OBS-80/43.

Guy, C. S., and D. W. Willis. 1993. Statewide summary of sampling data for black and white crappies collected from South Dakota waters. South Dakota Department of Game, Fish and Parks, Fisheries Division Report 93-12, Pierre.

Guy, C. S., and D. W. Willis. 1995a. Growth of crappies in South Dakota waters. Journal of Freshwater Ecology 10:151-161.

Guy, C. S., and D. W. Willis. 1995b. Population characteristics of black crappies in South Dakota waters: a case for ecosystem-specific management. North American Journal of Fisheries Management 15: 754-765.

Kelso, W. E., and D. A. Rutherford. 1996. Collection, 
preservation, and identification of fish eggs and larvae. Pages 255-302 in B. R. Murphy and D. W. Willis, editors. Fisheries techniques, 2nd edition. American Fisheries Society, Bethesda, Maryland.

Koth, R. M. 1981. South Dakota lakes classification and inventory. South Dakota Department of Water and Natural Resources, Final Report, Pierre.

Maceina, M. J., P. W. Bettoli, and D. R. DeVries. 1994. Use of a split-plot analysis of variance design for repeated-measures fishery data. Fisheries 19(3):1420.

Mitzner, L. R. 1987. Classification of crappie spawning habitat in Rathbun Lake, Iowa, with reference to temperature, turbidity, substrate and wind. Iowa Department of Natural Resources, Technical Bulletin 1, Des Moines.

Overmann, G. J., R. D. Hoyt, and G. A. Kindschi. 1980. The larval life history of the crappies (Pomoxis spp.). Transactions of the Kentucky Academy of Science 41:105-115.

Pope, K. L., and D. W. Willis. 1997. Environmental characteristics of black crappie (Pomoxis nigromaculatus) nesting sites in two South Dakota waters. Ecology of Freshwater Fish 6:183-189.

Storck, T. W., D. W. Dufford, and K. T. Clement. 1978.
The distribution of limnetic fish larvae in a flood control reservoir in central Illinois. Transactions of the American Fisheries Society 107:419-424.

Thornton, K. W. 1990. Perspectives on reservoir limnology. Pages 1-13 in K. W. Thornton, B. L. Kimmel, and F. E. Payne, editors. Reservoir limnology: ecological perspectives. Wiley, New York.

Thornton, K. W., and five coauthors. 1981. Reservoir sedimentation and water quality-a heuristic model. Pages 654-661 in H. G. Stefen, editor. Proceedings of the symposium on surface water impoundments. American Society of Civil Engineers, New York.

Tuberville, J. D. 1979. Vertical distribution of ichthyoplankton in upper Nickajack Reservoir, Tennessee, with comparison of three sampling methodologies. Pages 185-203 in R. D. Hoyt, editor. Proceedings of the third symposium on larval fish. Western Kentucky University, Department of Biology, Bowling Green.

Werner, R. G. 1969. Ecology of limnetic bluegill (Lepomis macrochirus) fry in Crane Lake, Indiana. American Midland Naturalist 81:164-181.

Received May 8, 1997 Accepted October 6, 1997 